\title{
Tingkat Keterampilan Dribling Sepak Bola pada SMP Al-Irsyad Surakarta
}

\author{
Achmad Rizal Lukman'), Sigit Aldianto2), Enggar Jati Praktikto ${ }^{3)}$. \\ Fakultas Keguruan \\ Universitas Muhammadiyah Surakarta \\ achmadr671@gmail.com \\ doi: $x x x$ xxx xxx
}

\begin{abstract}
Abstrak: Penelitian ini dilatarbelakangi oleh belum diketahuinya kemampuan keterampilan menggiring bola pada siswa SMP Al-Irsyad SURAKARTA. Sampel penelitian sebanyak 15 siswa yang diambil dari kelas 7c SMP AL-Irsyad SURAKARTA. Penelitian dilakukan dengan metode survei dan teknik pengumpulan datanya menggunakan teknik tes dan pengukuran. Tujuan dalam penelitian ini adalah untuk mengetahui keterampilan siswa dalam melakukan teknik dasar dribbling atau menggiring bola dalam permainan sepak bola. Dalam prosesnya pengambilan data test mengukur keterampilan, kelincahan, dan kecepatan kaki dalam memainkan bola menggunakan tes kemampuan menggiring bola (Nurhasan 2007: 212). Teknik pengumpulan data dilakukan dengan cara mengamati pelaksanaan kegiatan pembelajaran berupa praktek dilapangan dan pengumpulan data. Hasil penelitian menunjukkan bahwa sebagian besar prosentase siswa dalam menggiring bola adalah baik. Dari data diatas diketahui siswa yang memilki kemampuan mendribble bola baik sebanyak 1 siswa, siswa yang memiliki kemampuan yang cukup baik sebanyak 4 siswa,dan siswa yang memiliki kemampuan mendribble bola kurang baik sebanyak 10 siswa. Jika dipersentasikan maka akan menghasilkan itungan sebanyak $1 / 15 \times 100 \%=6,6 \%$ dari kemampuan baik, $4 / 15 \times 100 \%=26,6 \%$ dari kemampuan cukup baik, $10 / 15 \times 100 \%=66,6 \%$
\end{abstract}

Kata Kunci: dribbling sepakbola

\section{Pendahuluan}

Sepak bola merupakan permainan beregu yang sangat popular di dunia, entah itu orang tua, pemuda, remaja pasti mengetahui apa itu sepak bola. Di Indonesia sepak bola menjadi salah satu cabor favorit bagi setiap orang.

Di era sekarang ini, olahraga sepakbola merupakan salah satu cabang olahraga yang populer di dunia. Olahraga ini menjadi salah satu industri hebat di benua Eropa. Berkembangnya industri sepakbola di Eropa diikuti dengan nilai transfer pemain dan gaji pemain yang sangat tinggi. Hal ini akhirnya merambah juga di negara kita. Akhir- akhir ini di negara Indonesia olahraga sepakbola menjadi salah satu cabang olahraga yang mulai disoroti oleh masyarakat Indonesia. Adanya liga profesional di Indonesia membuat sepakbola Indonesia semakin baik. Gaji pemain dan pelatih pun juga semakin besar seiring dengan perkembangannya. Turnamen-turnamen sepakbola dari berbagai usia juga banyak dilaksanakan, mulai dari 
usia 10 tahun, 12 tahun, 14 tahun, 16 tahun, 19 tahun, 21 tahun dan 23 tahun. Selain turnamen kelompok umur, pada tingkat pendidikan juga sering diselenggarakan turnamen sepakbola seperti dalam event Porseni, OOSN, Liga Pelajar Indonesia (LPI) dan turnamen-turnamen yang lainnya.

Sepak bola merupakan permainan yang banyak menguras tenaga. Maka dari itu membutuhkan banyak latihan fisik untuk menjaga stamina tetap prima dalam bertanding, disamping stamina sepak bola juga memerlukan penguasaan teknik dasar. Diantaranya adalah dribbling, passing, dan shooting.

Dribbling adalah menggiring bola atau membawa bola, mempercepat, membelokkan bola, dan menghentikan bola. Dribbling menuntut pemain memiliki control bola yang bagus. Tak jarang banyak pemain bola kuwalahan dalam merebut bola dari pemain yang memiliki control dribble yang baik.

Kemampuan menggiring bola dalam bermain sepakbola merupakan suatu kemampuan dasar yang harus bisa dikuasai oleh pemain sepakbola. Dengan kemampuan menggiring bola yang baik, seorang pamain dapat melewati lawan dengan mudah kemudian memberikan umpan atau melakukan tembakan ke gawang lawan sehingga peluang terciptanya gol akan semakin banyak. Hal ini berarti bahwa kemampuan menggiring bola dapat mempengaruhi kemampuan bermain sepakbola seseorang. Selain itu, melalui kemampuan menggiring bola dapat dilihat kelak seseorang tersebut masuk dalam posisi bagian yang berada dalam tim.

Dalam penggunaan tekhnik dasar dribble tidak hanya memerlukan teknik penguasaan bola yang baik tetapi juga memerlukan sprint yang cepat dan kelincahan. Jika aspek tersebut di padukan maka seorang pemain dapat menjadi kunci dari suatu permainan bola.

Dari uraian di atas penulis tertarik untuk melakukan penelitian dengan judul Tingkat Keterampilan Dribling Sepak Bola Pada Smp Al Irsyad Surakarta

Dari uraian di atas dapat di simpulkan bahwa permasalahan di SMP AL IRSYAD SURAKARTA adalah seberapa besar tingkat kemampuan menggiring bola siswa. Tujuan yang ingin dicapai dalam penelitian ini adalah untuk mengetahui seeberapa besar tingkat kemampuan menggiring bola pada siswa SMP AL IRSYAD SURAKARTA.

\section{Metode}

Dalam pengumpulan data penelitian ini menggunakan metode survei dan teknik pengumpulan data menggunakan teknik tes dan pengukuran. Metode penelitian dirancang untuk mengumpulkan informasi tentang keadaan nyata sekarang yang selanjutnya dipresentasikan. 
Dalam prosesnya pengambilan data test mengukur keterampilan, kelincahan, dan kecepatan kaki dalam memainkan bola.Tes Kemampuan Menggiring Bola (Nurhasan 2007: 212).

Alat yang digunakan yaitu bola, stopwatch, 6 buah( kun), tiang bendera, dan kapur. Berikut tahapan yang dilakukan.

1. Pada aba-aba "siap" testee berdiri di belakang garis start dengan bola dalam penguasaan kakinya.

2. Pada aba-aba "Ya" testee mulai menggiring bola ke arah kiri melewati rintangan pertama dan selanjutnya menuju rintangan berikutnya sesuai dengan arah panah yang telah ditetapkan sampai ia melewati garis finish.

3. Salah arah dalam menggiring bola, ia harus memperbaikinya tanpa menggunakan anggota badan selain kaki di mana melakukan kesalahan dan selama itu pula stopwatch tetap jalan.

4. Menggiring bola dilakukan oleh kaki kanan dan kiri secara bergantian, atau minimal salah satu kaki pernah menyentuh bola satu kali sentuhan.

\section{Hasil dan Pembahasan}

Pengambilan data dilakukan pada siswa dari kelas 7C program khusus yang berjumlah 15 orang, dan dilaksanakan pada tanggal 11 februari 2019. Dapat di ketahui bahwa hasil dari pengambilan data disajikan pada Tabel 1 berikut. 
Tabel 1. Hasil Pengambilan Data Dribbling

\begin{tabular}{|c|l|l|}
\hline No & \multicolumn{1}{|c|}{ Kode } & \multicolumn{1}{c|}{ waktu } \\
\hline 1 & Fathurahman & $25 \mathrm{dtk}$ \\
\hline 2 & Muhammad Riski & $28 \mathrm{dtk}$ \\
\hline 3 & Gagah Pamungkas & $24 \mathrm{dtk}$ \\
\hline 4 & Lukman Hakim & $30 \mathrm{dtk}$ \\
\hline 5 & Ari Afandi & $23 \mathrm{dtk}$ \\
\hline 6 & Imam Fajar indah & $32 \mathrm{dtk}$ \\
\hline 7 & Aldi taher & $35 \mathrm{dtk}$ \\
\hline 8 & Fahriza Hilmi & $31 \mathrm{dtk}$ \\
\hline 9 & Achmad Muzaki & $20 \mathrm{dtk}$ \\
\hline 10 & Ari puji raharjo & $31 \mathrm{dtk}$ \\
\hline 11 & Abdul Gofur & $55 \mathrm{dtk}$ \\
\hline 12 & Putut Satria & $22 \mathrm{dtk}$ \\
\hline 13 & Ferry Dwi Irawan & $33 \mathrm{dtk}$ \\
\hline 14 & Dwi Nur Rokis & $33 \mathrm{dtk}$ \\
\hline 15 & Adit Setiawan & $26 \mathrm{dtk}$ \\
\hline
\end{tabular}

Dalam penilaian diatas menggunakan sistem waktu dengan pembagian tingkat dikatakan baik dengan waktu 20 detik atau kurang,dan diatakan cukup baik apa bila waktu peserta 25 detik atau kurang, siswa di katakan kurang apabila waktu test dari peserta lebih dari 25.

Dari data diatas diketahui siswa yang memilki kemampuan mendribble bola baik sebanyak 1 siswa, siswa yang memiliki kemampuan yang cukup baik sebanyak 4 siswa,dan siswa yang memiliki kemampuan mendribble bola kurang baik sebanyak 10 siswa. Jika dipersentasikan maka akan menghasilkan itungan sebanyak 1/15 $\mathrm{x} 100 \%=6,6 \%$ dari kemampuan baik, $4 / 15 \times 100 \%=26,6 \%$ dari kemampuan cukup baik, $10 / 15$ x $100 \%=66,6 \%$ maka akan menghasilkan data grafik 1 sebagai berikut.

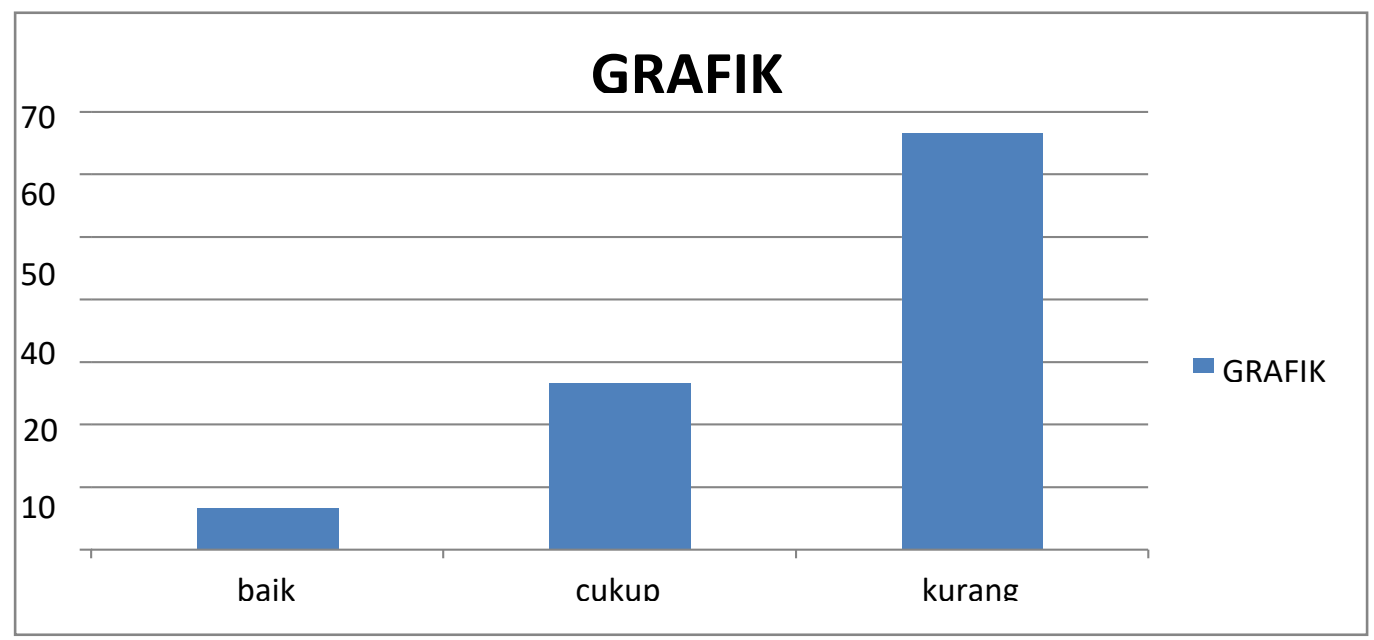

Gambar 1. Klasifikasi Kemampuan Dribbling Siswa 
Dari tabel grafik diatas, sebagian besar siswa yang kurang baik dalam melakukan dribble bola lebih tinggi atau banyak yang belum bisa menguasai teknik dasar dalam permainan sepak bola karena dalam pembelajaran guru menyampaikan hanya sebatas pengetahuan dan tidak dibina secara intensif dan juga jam pertemuan yang dikurangi mengakibatkan tidak efektifnya kegiatan pembelajaran.

Maka dari itu untuk bisa meningkatkan kualitas atau memahami akan pembelajaran yang disampaikan teknik dasar permainan sepak bola dribble bola harus dilatih secara mandiri atau bisa juga dengan mengikuti ekstrakurikuler maupun sekolah sepak bola (SSB) diluar kegiatan pembelajaran dikelas dengan metode tersebut akan meningkatkan keterampilan yang dimiliki siswa tersebut dengan tujuan memperoleh nilai tertinggi disekolah pada saat penilaian praktek materi sepak bola dengan syarat harus bersungguh sungguh dalam kegiatan pembelajaran tersebut.

Penggunaan metode belajar diluar kegiatan jam pembelajaran dikelas seperti ekstrakurikuler maupun sekolah sepak bola (SSB) ini disampaikan dengan materi yang dimodifikasi supaya tidak menjadi membosankan dalam kegiatan tersebut sehingga memicu minat siswa untuk belajar dengan sungguh sungguh .

\section{Simpulan}

Setelah mengetahui keterampilan menggiring bola atau dribbling pada siswa SMP Al Irsyad Surakarta maka bisa disimpulkan bahwa tingkat keterampilan dribbling siswa SMP Al-Irsyad surakarta mayoritas belum menguasai sepenuhnya teknik dasar dalam permainan sepak bola salah satunya adalah teknik dribbling ,untuk bisa memahami secara mendalam diharuskan siswa-siswa berlatih teknik dribbling sepak bola dengan menambah jam belajar sendiri seperti latian mandiri, ekstrakurikurer, dan juga sekolah sepak bola (SSB).

\section{Daftar Pustaka}

Nurhasan. (2007). Tes dan Pengukuran Dalam Pendidikan Jasmani. Jakarta: Depdiknas.

Remmy Mochtar. (1992). Olahraga Pilihan Sepakbola. Jakarta:

Dirjendikti Proyek Pembinaan Tenaga.

Sucipto, Dkk. (2000). Sepakbola. Jakarta: Dirjendikti.

Suharsimi Arikunto. (2006). Prosedur Penelitian Suatu Pendekatan Praktek. Jakarta: Rineka Cipta.

Sukatamsi. (1984). Teknik Dasar Bermain Sepakbola. Solo: Tiga

Serangkai. 40

(2001). Permainan Besar I Sepakbola. Jakarta: Universitas Terbuka. Erik Kurniawan. (2015). Skripsi Tugas Akhir. Jogja: Universitas negri jogjakarta. 